\title{
Preliminary assessment for coastal climate adaptation and resilience in Kepetingan Hamlet, Sawohan Village, Sidoarjo Regency
}

\author{
Fibrilatifa Adityawitari ${ }^{1}$, Dhira K. Saputra ${ }^{1,2^{*}}$ and Ardanti Y. C. Sutarto ${ }^{3}$ \\ ${ }^{1}$ Marine Science Study Program, FFMS, Universitas Brawijaya, Malang, Indonesia \\ ${ }^{2}$ CORECT-RG, Universitas Brawijaya, Malang, Indonesia \\ ${ }^{3}$ USAID APIK (Climate Change Adaptation and Resilience), East Java, Indonesia
}

\begin{abstract}
Climate change has been occurring in every part of the world for the last two decades, including Indonesia. This phenomenon constitutes key emerging threat to marine ecosystems and fisheries resources as well as to societies that depend on these coastal environment and natural resources for food and livelihood. Nowadays, coastal adaptation to climate change is one of the tremendous challenges for coastal communities. The east coast of Sidoarjo regency has one of the widest mudflat areas in East Java, with high sedimentation rate which is originated from Brantas Watershed. This area, specifically in Kepetingan Hamlet, Sawohan Village, is heavily impacted by tidal floods twice a year and this is considered the most vulnerable place in Sidoarjo coastal area. In terms of a climate change adaptation measures, it is important to assess the resilience of these communities. This research aimed to analyse the recent condition of Kepetingan Hamlet and to investigate the factors which increases local community vulnerability due to climate change impact. We conducted this research by undergoing field observations including interviews with related stakeholders. This result expected to provide a bigger picture about Kepetingan Hamlet and to provide the suitable adaptation strategies for building resilience in facing climate change.
\end{abstract}

\section{Introduction}

Global climate change has given great ecological impacts mainly on the coastal areas and the surrounding societies (sea level rise inundation, increased storm surges, saltwater intrusion and sea water quality deterioration). These impacts will affect natural resources, population, biodiversity, economic activities and future development, therefore can affect increased attention of decision-makers and coastal managers from various levels [6]. Coastal adaptation to climate change is one of the tremendous challenges in facing vulnerable coastal communities. Coastal communities are prone to various stressors related to climate change, particularly change in ocean temperature, loss of habitat, biodiversity degradation and natural hazards such as sea level rise, tidal flood and storms. Rural coastal communities are

*Corresponding author: saputra.dhira@ub.ac.id 
extremely vulnerable due to their approximately high exposure and sensitivity towards direct proximity to climatic hazards. They often lack environmental awareness and well-developed critical care services as a risk reduction prevention also economic resilience that enable them to have alternative financial resources. Moreover, because these coastal communities are often isolated and have lower fitness to meet environmental changes which affected economically stressed, thus they may have limited access to both resources, such as technical and financial, needed for adaptation [2].

The effects of climate change are actual and require actions. These actions called "the three pillars of response to climate change", including mitigation, adaptation and resilience. Adaptation refers to an action to reduce vulnerability to climate change impacts and to adjust to cope with actual or expected changes in climate. These environmental impacts of adaptation are receiving slight attention in policy design, decision-making and regulations [1].

Coastline area have a high vulnerability rate to climatic hazards, particularly induced sealevel rise and tropical cyclones. The need of risk-informed planning of coastal regions through analysing the areas at diverse of climatic risk levels and a comprehension of fundamental factors for resolve these challenges is crucial. Kepetingan Hamlet has a 9,7 km coastline with two-thirds of the area used as shrimp or milkfish farms (Figure 1). Tidal flood is a natural disaster that regularly happens in Kepetingan Hamlet. The increase in sea level rise and high rate of rainfall during the rainy season resulted in farmers experiencing considerable losses. The impact of damage that always occurs causes farms productivity to decline. Even worse, this hazard might break down the farm's dykes, so the costs incurred for maintenance and repairs are higher than the income received.

Aim of this research is to analyse the condition in a remote Kepetingan Hamlet in facing climate change challenges, as well as to determine the suitable solutions regarding those condition from socio-economic resilience approaches. Primary environmental data were collected from Kepetingan Hamlet, Kepetingan River and Permisan Bay. Descriptive analysis is presented as preliminary look at the coastal climate adaptation and resilience in Kepetingan.

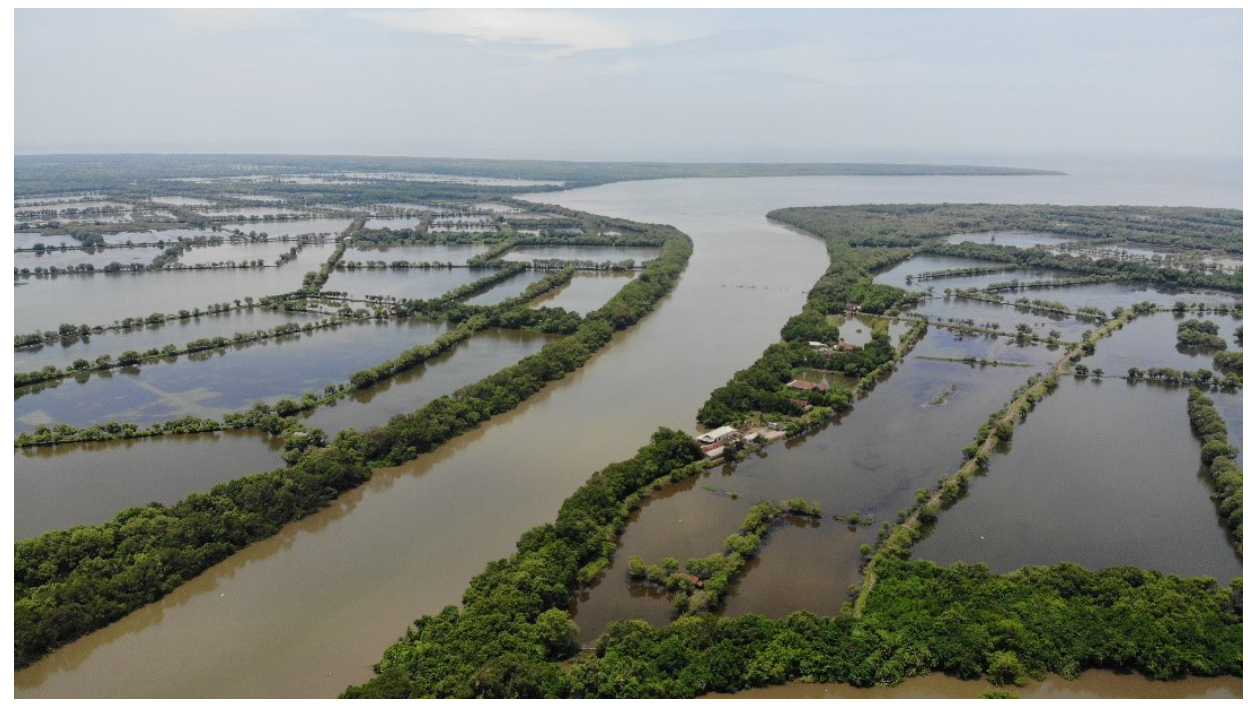

Fig. 1. Aerial photography of Kepetingan River estuary. Most of mangrove areas were converted to the tranditional shrimp farms (source: AMAF East Java Province B.O. Kepanjen) 


\section{Methodology}

\subsection{Study site and data collection}

The research was conducted from June 2019 to September 2019. Kepetingan Hamlet located in the border of Buduran District, $14 \mathrm{~km}$ from the capital of Sidoarjo Regency, East Java Kepetingan Hamlet has an area of $27,30 \mathrm{~km}^{2}$, adjacent to Permisan Bay (Figure 2). This region is only acessed with boat through Kepetingan River during rainy season.

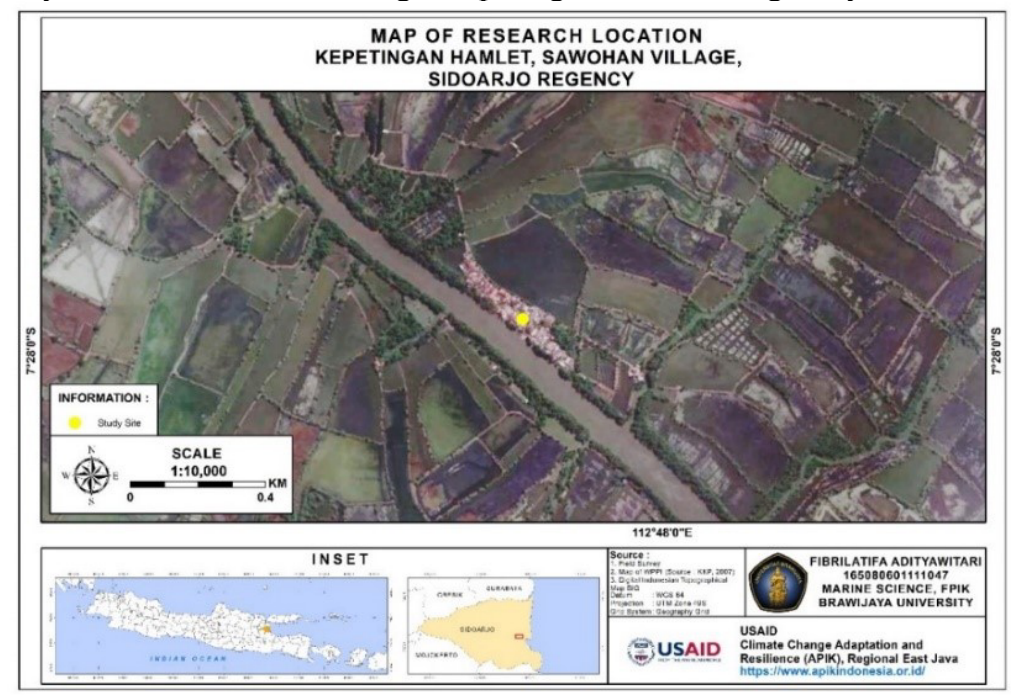

Fig. 2. Map of research location

A set of field observations and interviews with key stakeholders were carried out during this study. Furthermore, secondary data including a broad range of documents collected from various perspectives and sources. Scientific publications and 'grey' literature (unpublished document and reports) were selected to obtain additional resources related to climate adaptation and resilience. Descriptive analysis were given to these datasets obtained from the field activities. Final result expected to generate ideas for suitable adaptation and resilience actions in the Kepetingan Hamlet.

\section{Result and discussions}

\subsection{Geographical conditions}

\subsubsection{Landscape}

Sidoarjo Regency considered as delta area, flanked by two of Brantas River watersheds (DAS), namely Porong River and Mas River, thus the agricultural land is very fertile and has good fisheries potential. Sawohan Village is one of 15 villages located in Buduran District, Sidoarjo Regency. Kepetingan Hamlet belongs to Sawohan Village, as the remote area surrounded by shrimp farms and milfish farms. The elevation is at 29 masl with the area cover up 27,30 $\mathrm{km}^{2}$. Kepetingan Hamlet has a very wide area that takes $34.44 \%$ of the entire area of Buduran District. There are $156 \mathrm{Ha}$ of dry land are used as residential areas, while another 2.574 ha are used as fish or shrimp farms (Figure 3). 


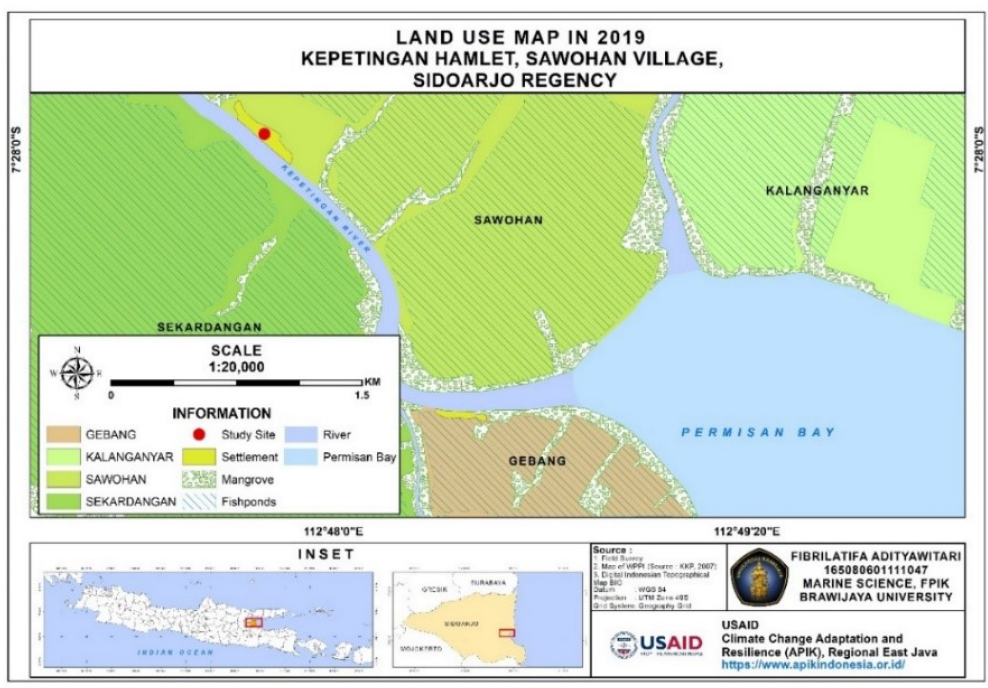

Fig. 3. Land Use Map of Kepetingan Hamlet in 2019

The location of Kepetingan Hamlet is arguably quite an isolated lowland, bordered with Madura Strait, Permisan Bay and surrounded by fish farms. The access to Kepetingan Hamlet consists of by two routes, both land (motorcylce via farm dykes) and water (boat). The land route approximately 30-45 minutes and can only be bypassed during the dry season. For the water route, it takes 45-60 minutes by motorboat (local people call it "Barito") through Kepetingan River. The depth of the river is about 7 meters at high tide and 3 meters at low tide. Kepetingan Hamlet located in the riverside of Kepetingan downstream, which empties to Permisan Bay. This area has a width of 500 meters and depth about 10 meters during high tide.

\subsubsection{Climate and weather}

Kepetingan Hamlet has a tropical climate with 5 months of rainy days and and peak rainfall in March. Tidal floods occured twice a year, each of rainy and dry season (Table 1). Spring tide starts from 21.00 WIB, with the high water lasting over 10 hours (until $09.00-12.00$ WIB). Houses with low foundation $(<30 \mathrm{~cm})$ would be inundated during this period of time. The average rainfall of this hamlet is $75,75 \mathrm{~mm} / \mathrm{yr}$. During rainy season, flooding occurred due to runoff from the Kepetingan watershed. This will aggravate the inundation level in Kepetingan.

Table 1. Seasonal calendar of Kepetingan Hamlet

\begin{tabular}{|c|c|c|c|c|c|c|c|c|c|c|c|c|}
\hline \multirow{2}{*}{$\begin{array}{c}\text { Site } \\
\text { Problems }\end{array}$} & \multicolumn{2}{|c|}{ Transition Season } & \multicolumn{5}{c|}{ Dry Season } & \multicolumn{5}{c|}{ Rainy Season } \\
\cline { 2 - 12 } & Mar & Apr & May & Jun & Jul & Aug & Sep & Oct & Nov & De & Jan & Feb \\
\hline $\begin{array}{c}\text { Tidal } \\
\text { flood }\end{array}$ & & & & & & & & & & & & \\
\hline $\begin{array}{c}\text { Sea water } \\
\text { overflow }\end{array}$ & & & & & & & & & & & & \\
\hline $\begin{array}{c}\text { Lack of } \\
\text { freshwater } \\
\text { catchment }\end{array}$ & & & & & & & & & & & & \\
\hline
\end{tabular}




\subsubsection{Mangrove}

Estuary habitat plays important role for the community and ecosystem. Kepetingan has a slightly high biodiversity of aquatic plants and animals. Various mangrove species can be found in Kepetingan dan Permisan Bay, includes nipa palm (Nypa fruticans), grey/white mangrove (Avicennia marina, Avicennia alba), tall-stilt mangrove (Rhizophora apiculata), milky mangrove (Excoecaria agallocha), holly-leaved acanthus/sea holly (Acanthus ilicifolius), mangrove apple (Sonneratia alba) and loop-root/red mangrove (Rhizophora mucronata).

\subsubsection{Faunae}

High economic faunae can be found in the region, includes crustaceans: mangrove crabs (Scylla spp), and tiger shrimp (Penaeus monodon); fishes: mozambique tilapia (Oreochromis mossambicus), milkfish (Chanos chanos), hawaiian ladyfish (Elops hawaiensis), nile tilapia (Oreochromis niloticus) and keting fish (Mystus sp.); mollusks: blood cockle/blood clam (Anadara granosa), manila clam,/japanese littleneck clam (Venerupis philippinarum) and antique ark (Anadara antiquata); reptiles: lizards (Varanus sp.), water snakes (Cerberus sp.) and estuarine crocodiles (Crocodylus porosus); primates: long-tailed macaques (Macaca fascicularis) and other species includes eels (Monopterus albus). This region also recognized as habitat or stopover for 27 species of birds and long migratory seabirds [3].

\subsection{Socio-economic conditions}

Kepetingan Hamlet is included in the category of a remote hamlet, due to the difficulty of transportation needed, hence all prices of primary, secondary and tertiary goods increase dramatically, as well as lack of telecommunication networks. The increased price is caused by all of goods supplied from outside of Kepetingan Hamlet and transported by motorboat. There are 107 families from the total population of 360 people. In general, the community of Kepetingan is in the middle economic level.

Local livelihoods dominated by farms labour and river/estuary fishermen, while another jobs includes government employees, entrepreneurs, farmers, and traders. However, the number of unemployed people is almost half of the productive population. Specifically, women who become housewives. Kepetingan Hamlet does not have adequate permanent health facilities. There is a small health facility which services are usually available for only once in a month, where the doctors and nurses are assigned from Bluru Village. Outside that regular examination scheduled, sick person must go to Sawohan or Bluru Village for better treatment.

\subsection{Disaster vulnerability assessment}

Communities and their livelihoods are affected by disasters and environmental vulnerabilities. Vulnerability to climate change and disasters is related straightly to the socioeconomic aspect of the community, also the individuals. A bigger community with a stable and secure socio-economic condition has lower vulnerability, vice versa.

Sea level rise which driven by climate change, is causing increased flooding during high tides along the coastal areas. Kepetingan Hamlet has a history of disasters relating to climate change, specifically tidal floods. Tidal floods are known as annual disasters that continue to happen more often. Tidal floods have struck Kepetingan Hamlet in a long time especially Kepetingan farm areas. There is no exact information about when this tidal flood began to strike the communities in Kepetingan and giving them a negative impact on farm 
productivity. In the old times, the elevation of the land was 2 meters, which was used to prevent land from high-tide flooding.

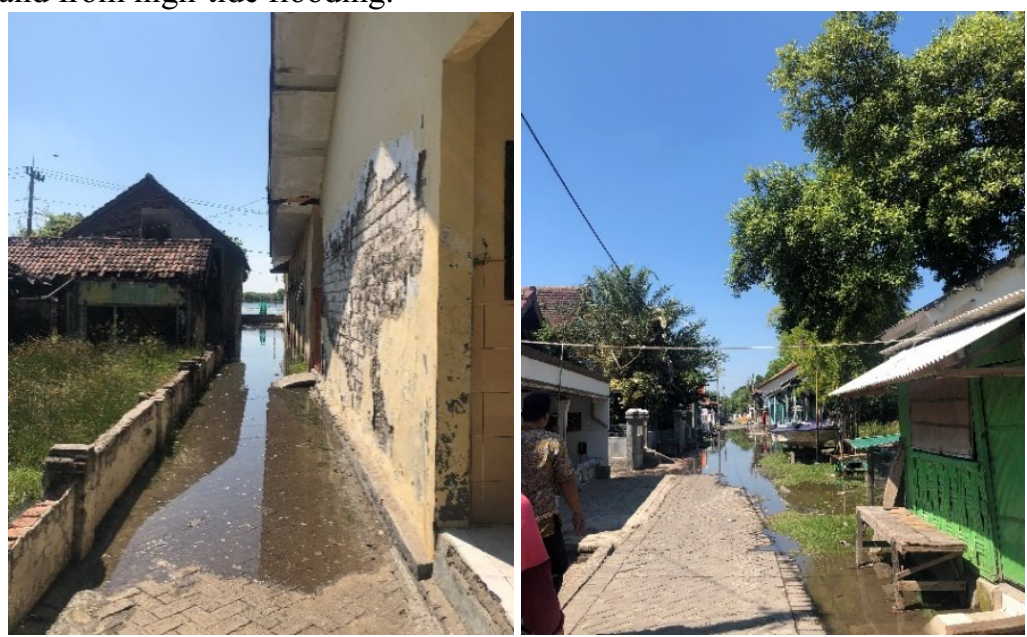

Fig. 4. Some areas in Kepetingan Hamlet are inundated during daily high tides

There was high-tide flooding in 2003. The damage of this tidal flood caused huge losses for farm farmers because it broke down the (soil constructed) dykes. From 2003 to 2016, some of damaged farms cannot be operated due to lack of funds for re-construction. The worst tidal flood happened in late 2017 with affected area of 1500-2000 Ha. This tidal flood gave a large amount of misfortune to farm farmers because this tidal flood was damaging and submerging 2/3 of farms area entire Kepetingan. Years after, the scale and intensity of tidal flood were decrease but overall flood height in recent years definitely higher than previous decades.

High-tide flooding usually occurs 2 times a year, with day-time flood occurring in the middle of the year around May to July and night-time flood occurring at the end of the year around November to January. Farms activities can be carried out effectively in the months with no threats from tidal flood months are not present (i.e February, March, April, August, September and October). The farmer's low ability to build strong (casted) embankments resulted into continuously damaged farms when tidal floods occured regularly in this area.

The vulnerability increases as mangrove vegetation which role as tidal wave breaker and energy absorber continuously cleared by illegal loging activity. In addition, increasing runoff from upstream Kepetingan River increases every year and resulted into higher volume of inundation. Local community also reported the land subsidence of $1 \mathrm{~m}$ within last 30 years $(1980-2019)$. Once every two years, local community have to elevate (reconstruct) the floor of the houses due to increasing level of intundation and land subsidence event.

The cost for repairing the farms and other disaster related expenses are causing financial problems for the families of the farm farmers. Most of the local community only depend on farm activities as main income. The lack of expertise other than aquaculture is one of reasons why local community do not have alternative livelihood. Tidal flood affected many aspects of life for local people. As shown above, in this climatic-disaster case, financial capability of community as well as individuals affects the capacity to deal with existing vulnerabilities. Communities with economically vulnerable have higher dependency on a highly fragile environment, such as mangrove ecosystem and other natural resources. People amass mangrove and estuary habitat in Kepetingan to fulfill their daily necessity, thus any interference refer to climate change can negatively influence their local earning. 


\subsection{Building Resilience of Kepetingan Hamlet to Changing Climate Through Ecosystem Management}

\section{Management measures}

There are several suitable strategies that can be used as action plans for building resilience of Kepetingan Hamlet to these impacts of climate change through management of ecosystems, which include the following:

- Preserving existing healthy mangrove ecosystems to maintain resilience

- Restoring degraded mangroves and conserving biodiversity

- Adaptation action needed from socio-economic aspect

\section{Adaptation measures from socio-economic perspective: alternative livelihood from eco and cultural tourism}

Adaptation refers to adjustments in ecological, social, or economic systems in response to actual or expected climatic stimuli and their effects or impacts. [7]. Adaptation action can be seen from various aspects of life. One of the many aspects is socio-economic perspective. In Kepetingan, socio-economic the most affected aspect in facing the challenges of climate change. Damaged farms which directly impact the primary livelihood represents one of those challenges. To cope with these problems, the action plan needed is to find alternative livelihood which can support local people well-being.

Based on the natural landscape of Kepetingan Hamlet, tourism activities have been suggested as an alternative to accommodate the needs for resources and resource protection. Ecotourism prioritizing the importance of mangrove conservation as well as advantages to the economic sector, therefore this can be included in the action plan of the adaptation to climate change, especially in Kepetingan Hamlet. This action plan can give local communities alternative incomes when their main livelihood cannot be implemented due to external factors (natural disaster).

The tourism sector has been initiated by the existence of these two tours. In Kepetingan Hamlet, there are already two tourism attractions which have been running for a long time but not included in the ecotourism category. These tours are called cultural tourism of Dewi Sekardadu and Nyadran Sea Ceremony. Putri Ayu Dewi Sekardadu is the daughter of Prabu Menak Sembuyu, Ruler of Blambangan Kingdom of Banyuwangi in the 14th century and believed as the mother of great Islamic figure in Java, Sunan Giri. A total of 400- 800 local and regional visitors come each weekend.

On the other hand, mangrove ecosystems have the potential to developed into ecotourism products, i.e mangrove educational tours and tracking. Canoeing, fishing, boating and birdwatching among ecotourism potential products in the Kepetingan. With the proper SOP in terms of ecotourism management, sustainable community-based ecotourism packages might become a long-term strategy for Kepetingan Hamlet climate change adaptation and resilience program. 


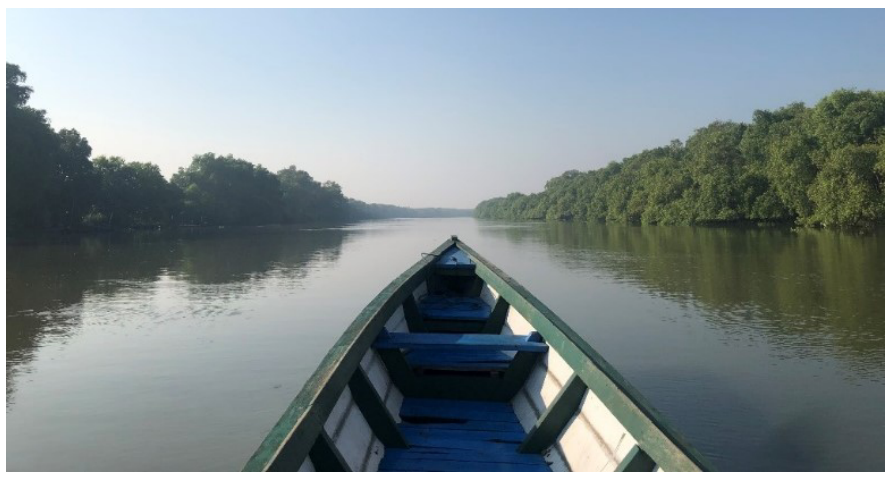

Fig. 6. Boating on Kepetingan estuary as one of the ecotourism product

\section{Conclusions}

Environmental and socio-economic conditions in Kepetingan Hamlet, resulted into higher vulnerability to climate risks. Enhancing the resilience of the mangrove ecosystem may decrease its vulnerability to climate change as well as provide alternative livelihood for local people. From the socio-economic (alternative livelihood) perspective, the adaptation action proposed to the community of Kepetingan Hamlet is tourism (cultural tourism and mangrove ecotourism). The uniqueness of Kepetingan landscape potentially further developed into various ecotourism products. This adaptation recommendation expected to establish a sustainable community-based adaptation which uses a benefit-sharing system, thus can gives local communities responsibility in conserving critical habitats as well as receiving direct economy benefits from those actions.

Authors thanks USAID Climate Change Adaptation and Resilience (APIK) Program, East Java Region for providing materials and field assistance during this research.

\section{References}

1. A. Enriquez-de-Salamanca, R. Ruben, R. M. Martin-Aranda, M. J. Santos, Env. Imp. A. R. 64, 87-96 (2017)

2. A.P. Fisher, World Dev. (2018)

3. R. Irawanto, Mangrove palm as a key species for bird habitat and their distribution in Ketingan, Sidoarjo in The 10th National Conference of Biology FKIP UNS, 18-174 (2013)

4. E. L. Malone, N. L. Engle, WIREs Cli. C. 2, 462-474 (2011)

5. M. Sajjad, J. C. L. Chan, Sci. T. Env. 671, 339-350 (2019)

6. S. Torresan, A. Critto, J. Rizzi, A. Zabeo, E. Furlan, A. Marcomini, Oce. Coast. M. 120, 49-63 (2016)

7. UNFCC (2019). What do adaptation to climate change and climate resilience mean?: The Big Picture, URL: https://unfccc.int/topics/adaptation-and-resilience/the-bigpicture/what-do-adaptation-to-climate-change-and-climate-resilience-mean 